FACTA UNIVERSITATIS

Series: Economics and Organization Vol. 17, No 4, 2020, pp. 329 - 341

https://doi.org/10.22190/FUEO200729024N

Original Scientific Paper

\title{
EXPLORING THE DIVERSITY WITHIN THE WORKPLACE OF SMALL FIRMS IN KOGI STATE, NIGERIA
}

\author{
UDC 159.942.4(669) \\ $331.101 .3(669)$
}

\section{Akeem Tunde Nafiu1, Unekwu Cynthia Alogwuja 2 , Dare Joseph Enimola ${ }^{2}$}

\begin{abstract}
${ }^{1}$ Centre for Pre-Degree \& Diploma Studies, Kogi State University, Nigeria ${ }^{2}$ Department of Business Administration, Faculty of Management Sciences, Kogi State University, Anyigba, Nigeria
\end{abstract}

\begin{abstract}
This study aimed at exploring diversity within the workplace of Small Firms in Kogi State, Nigeria. The study used survey research design. Descriptive statistics, mean score from Likert scale, ANOVA and multiple Regressions were used for data analysis. The study found that age has significant effect on job satisfaction of employees; and that religion, educational background and job experience have strong significant effect on small firms' organizational outcomes in Kogi State. The finding further indicated that gender difference affects organizational performance, job satisfaction, productivity, competitive advantage and customers' satisfaction. The study concluded that age has significant positive effect on job satisfaction; and other factors such as religion, educational background and job experience of employees only affect the performance of small firms in Kogi State positively. This study therefore recommended that ownermanagers of small firms should take cognizance of age as it affects job satisfaction of employees; and should strategically manage factors such as religion, educational background and job experience of employees as they affect performance.
\end{abstract}

Key words: Diversity, Job Satisfaction, Organizational Outcomes, Employee Turnover, Organizational Culture

JEL Classification: L20, M10

Received July 29, 2020 / Revised October 13, 2020 / Accepted October 19, 2020

Corresponding author: Akeem Tunde Nafiu

Centre For Pre-Degree and Diploma Studies, Kogi State University, Anyigba, Nigeria

E-mail: tundenafiu01@gmail.com

๑) 2020 by University of Niš, Serbia | Creative Commons Licence: CC BY-NC-ND 


\section{INTRODUCTION}

Organizational outcomes reflect what the small firms want to achieve in Kogi State. The outcomes of every organization are shaped by its internal and external environmental situations. For organizational outcomes to be realistic, an effective organizational framework must be put in place. According to Madanchian, Hussein, Noordin, \& Taherdoost (2017), organization outcomes may reflect corporate performance, job satisfaction, and improved decision. Gomez \& Bernet (2019) viewed organization outcomes in terms of "quality and financial performance" (p.383). Hwang \& Hopkins (2015) added that "organizational commitment, job satisfaction, and intention to leave" are aspects of organization outcomes (p.44). Organization outcomes may be productivity, competitive advantage and customers' satisfaction. Notably, organization outcomes are both internal and external. For instance, competitive advantage and customers' satisfaction are paradigm of the outcomes that are external to the organization while others are internal to the organization.

Organization outcomes may be predicted given diversity characteristics. Gomez \& Bernet (2019) argued that diversity has the propensity to improve performance. Diversity characteristics that place issues before managers of small firms in Kogi State are age, gender, race, religion, experiences, educational background and culture among employees. Saxena (2014) expressed that small firms have inventory of human resource with differences in age, gender, perception, attitude, caste, religion and region. Diversity reflects heterogeneity of characterizing variables in human, but the homogeneity perspective of it is important. This is because a group of employees may possess similar characteristics. For instance, employees within a group may be in the same age bracket, sex or have the same cultural background.

Today, SMEs now manage diversity with the aim of taking advantage of diverse employees' ability. This is targeted at creating a platform for the achievement of desirable outcomes. Pitts, Hicklin, Hawes \& Melton (2010) opined that there are scanty researches relative to how diversity management can be used to achieve desirable outcomes in diverse organizations. Rahman, Ferdausy and Bhattacharjee (2014) posited that the success of an organization depends on its workforce. Among different human resource management issues, workforce diversity has received a considerable, conceptual, and empirical attention in organizational area. The finding of Ibidunni et al. (2018) revealed that "workforce diversity significantly influences job satisfaction and commitment" (p.1052). A number of studies (Kalleberg \& Leicht, 1991; Gellner and Veen, 2009; Rehman, Ullah \& Abrar-ul-haq, 2015) revealed that "individual characteristics have considerable relationship with organization performance". Past studies have shown that diversity among employees culminates into both negative and positive effects (Kochan et al. 2003). Weiliang et al. (2011) attributed "the dual effect to lack of evidence linking workforce diversity to employee performance". However, Lindblad (n.d) clarified that diversity in the workplace is generally regarded as a positive one for SMEs, but a workforce that has significant differences in ethnicity, race, religion and gender may create destructive tendency at the enterprise.

The discussion above shows that there is relatively low empirical research on 'the influence of factors of workforce diversity on the organizational outcomes of small firms in Kogi State', Nigeria. The researcher is therefore induced to cover this gap by undertaking the present study. 
The main objective of this study is to explore the diversity within the workplace of Small Firms in Kogi State, Nigeria. The three identified objectives of the study are:

i. Ascertained gender difference with reference to the organizational outcomes of small firms in Kogi State; and

ii. Investigate the effect of diversity factors on the organizational outcomes of small firms in Kogi State.

\section{CONCEPTUAL REVIEW}

There are ample collections of scholarly conceptual definitions of diversity. Different perspectives are observed based on peculiarity in disciplines. The conceptual reviews on diversity in this study reflect the business management perspective. According to Lindblad (n.d), the Society for Human Resource Management defined "diversity as valuing the characteristics that make a person unique, such as age, ethnicity, education level and family background". The uniqueness as observed from the definition appears to implicitly or explicitly show that employees possess varying characteristics. This is similar to the addition of Kokemuller (2011) that diversity is the "presence of people from a wide range of backgrounds and possessing different traits". Also, Knippenberg et $a l$. (2004) opined that diversity refers to "an almost infinite number of dimensions, ranging from age to nationality, from religious background to functional background, from task skills to relational skills, and from political preference to sexual preference" (p.1015). Diversity research has "mainly focused on gender, age, race/ethnicity, tenure, educational background, and functional background" (Milliken \& Martins, 1996; Williams \& O'Reilly, 1998). However, Robbins (2009) refers to "workforce diversity as organizations that are becoming more heterogeneous with the mix of people in terms of gender, age, race, and education background". The term 'mix' in his broad definition appears to mean combination and interaction of people from diverse backgrounds. Ehimare \& OgagaOghene (2011) posited that "the main concern of this standpoint is that a broad definition may imply that all differences among people are the same" (p.95). Workforce diversity means the composite of people with different/similar psychological, sociological, economic and personality factors at the workplace.

Considering workforce diversity as effective tool for achieving the organizational outcomes of small business firms is very important. Workforce diversity may be constructive when managed effectively and destructive to organizational outcomes when managed poorly. The motive behind the effective management of workplace diversity is that the complexity in human element of organizational life is abrupt by dissimilarities in characteristics.

The "business benefits of workplace diversity have been widely contested since the idea was conceived" (Ehimare \& Ogaga-Oghene, 2011). There is an ongoing debate as to whether there is indeed any discernible business benefit (Mulholland, Ozbilgin \& Worman, 2005). It is however worthy of note that workforce diversity functions as a vehicle for organizational success through collection of wealth of experience and ideas. Lindblad (n.d) is of the "opinion that the inclusion of diverse individuals fosters a rich exchange of new ideas among employees and helps organization leverage the unique character of its workforce". Andrade (2010) discussed the benefits of workforce diversity in the workplace as follows: 
i. Increased Productivity: There is no doubt that some SMEs have collection of talents in their enterprise. SME owners can unfold the skills of their employees and take advantage of talents to deliver the best outcome through effective diversity management. It is important to note that diverse employees who have better knowledge of the cultural value of their enterprises may be induced to remain committed to productivity.

ii. Rising creativity and Problem-solving: There is possibility that employees have diverse intellectual properties. These may be useful for SMEs, and as such, managers may translate the intellectual properties into innovativeness, creativity, diversification and design of the best approach to solving business problems.

iii. Attracting and Retaining talent that add a competitive edge to any SMEs. SME owners/managers can make use of talented employees to distinct themselves in a competitive environment. When skills pool is increased, SMEs may be propelled either to compete in the international global world or to increase its diverse customer base in Nigeria.

iv. Help to build synergy in teams and enhances communication skills that brings in new attitudes and processes that profit the whole team

v. Applying the proper diversity and inclusion management strategies does not only save money on litigation expenses generated by discrimination lawsuits but is the right thing to do for the business.

vi. It increases market share and create a satisfied diverse customer base by relating to people from different backgrounds. It does propel the organization and its status to claim its place and success in the global business world of the $21^{\text {st }}$ century.

No organization ever exists without people from different and similar background. Professionals in the field of human resources must be happy gathering diverse employees for scientifically designed job, and manage such diversity for organizational success. The ability of any organization to plan and manage workforce diversity promotes the tendency of achieving a desired goal. Some small firms find it difficult to be successful today, because of their ill-commitment to ensuring that workforce diversity is part of their day-to-day business conduct. This backdrop may be tied to the fact that owner-managers of these small firms have low know-how on effective practice of diversity management, and the contributory elements in the successful management of diversity, and task that can deal with diversity related issues in their workplace. For effective diversity management practice, Kokemuller (2011) established that "top management and front-line managers in a diverse organization have to set the tone for an effective culture, as this will promote nondiscriminatory work environment, and fair treatment of all workers in the hiring process, job conditions, work evaluations and promotions". Loriann and Carol (2007) insisted that "un-managed diversity is more likely to damage morale, increase turnover, and cause significant communication problems and conflict within the organization".

Though, there have been controversies regarding the influence of workforce diversity on organizational outcomes for many decades. Milliken and Martins (1996) understand that "the influence of diversity on organizational outcomes, such as organizational performance, employee satisfaction, and turnover, is essential". It is believed that diversity is related to organizational outcomes and success. The organizational outcomes considered for the purpose of this study are organizational performance, job satisfaction, productivity, turnover and competitive advantage. It appears that workforce diversity has a correlative impact on each of these variables, particularly in a complex managerial and organizational environment. 
Anderson \& Metcalfe (2003) argued that "the paucity of stout research examining the impact of diversity upon businesses has raised questions about the existence of any connection between workforce diversity and business outcomes". Though today, there is increased number of quality researches (Cox et al., 1991; Webber and Donahue, 2001; SeyedMahmoud, 2004; Roberge and Rolf, 2010; Patrick and Kumar, 2012) which have proven the workforce diversity has both positive and negative effect on organizational performance. This made Choi \& Rainey (2010) to express that "previous empirical research on the effects of workforce diversity on organizational performance has found mixed results". Other researches (Kalleberg \& Leicht, 1991; Weiliang et al. 2011; Rehman et al., 2015) also proved the effect of individual workforce diversity factors on other organizational outcome.

Diversity factors are comparatively explained by the atmosphere of a particular organization and the external environment in which it sub-systemizes. Two organizations may likely witness varying course of workforce diversity due to national or regional factors. The observed fact that has been missing in previous researches is that workforce diversity varies based on economy, individual orientation and organizational culture from country to countries. This implies that research reports are likely to vary according to these factors. This may be a clarification to the studies (Bell \& Berry, 2007; Klein \& Harrison, 2007) with the position that previous researches analyzed "the impacts of diversity taking into account the complex reality of organizations". The issue is that social and functional factors which are causal of diversity have predictive power on the outcome of small firms. These factors determine the extent at which salient organizational behaviour is approved by organizational members, and this remains the reason it has become essential for effective workforce diversity management. The study of Choi \& Rainey (2010) shows "how managerial efforts and other contextual variables (such as diversity management, organizational culture, and team processes) moderate the relationship between diversity and organizational outcomes" (p.102).

\section{Methodology}

The study premised on 'survey research design'. The study's population comprised of employees and owner-managers of selected small firms. A purposive sample technique was used to select employees (216) and owner-managers (59) from the selected small firms in Kogi State. The choice of this technique was supported with the fact that there is no adequate data regarding small firms in Kogi State. A well-structured questionnaire was used for gathering primary data. The questionnaire was administered to two categories of respondents (216 employees and 59 owner-managers) in the study area with the aid of five trained research-assistants. The constructs of this questionnaire were validated by a panel of professionals from the field of industrial relation/human resource management. For the aim of this study, 'questionnaire' was scaled and its reliability was subsequently tested through Cronbach's alpha. This study analyzed data using 'descriptive statistics, Analysis of Variance (ANOVA) and regression model'. The model is specified as follows:

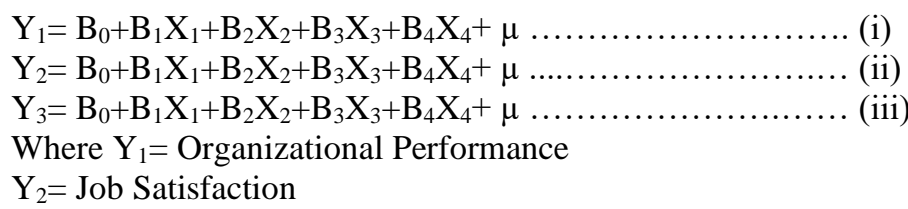

here $\mathrm{Y}_{1}=$ Organizational Performance 
$\mathrm{Y}_{3}=$ Employee Turnover

$\mathrm{X}_{1}=$ Employee Age

$\mathrm{X}_{2}=$ Religion

$\mathrm{X}_{3}=$ Education Background

$\mathrm{X}_{4}=$ Job Experience

$\mathrm{B}_{0}=$ intercept

$\mathrm{B}_{1}$ to $\mathrm{B}_{8}=$ coefficient to be estimated and

$\mathrm{X}_{1}$ to $\mathrm{X}_{2}$ are the independent variables.

\section{RESUlTS AND DISCUSSION}

Table 1 Socio-demographic variables of the respondents

\begin{tabular}{|c|c|c|c|c|c|}
\hline \multirow[t]{2}{*}{ Responses } & \multicolumn{3}{|c|}{ Frequency } & \multirow[t]{2}{*}{ Percentage } & \multirow[t]{2}{*}{ Mean/Mode } \\
\hline & Employees & Owner/Managers & Total & & \\
\hline \multicolumn{6}{|l|}{ Age } \\
\hline $15-25$ & 45 & 6 & 51 & 18.55 & \multirow{6}{*}{38.84} \\
\hline $26-36$ & 75 & 22 & 97 & 35.27 & \\
\hline $37-47$ & 20 & 17 & 37 & 13.45 & \\
\hline $48-58$ & 46 & 14 & 60 & 21.82 & \\
\hline $59 \&$ Above & 30 & - & 30 & 10.91 & \\
\hline Total & 216 & 59 & 275 & 100 & \\
\hline \multicolumn{6}{|l|}{ Gender } \\
\hline Male & 85 & 33 & 118 & 42.91 & \multirow{3}{*}{157} \\
\hline Female & 131 & 26 & 157 & 57.09 & \\
\hline Total & 216 & 59 & 275 & 100 & \\
\hline \multicolumn{6}{|l|}{ Education } \\
\hline FSLC & 15 & - & 15 & 5.45 & \multirow{6}{*}{114} \\
\hline SSCE & 47 & 13 & 60 & 21.82 & \\
\hline NCE/OND & 86 & 28 & 114 & 41.45 & \\
\hline $\mathrm{HND/BSc}$ & 52 & 8 & 60 & 21.82 & \\
\hline MSc \& above & 16 & 10 & 26 & 9.45 & \\
\hline Total & 216 & 59 & 275 & 100 & \\
\hline \multicolumn{6}{|l|}{ Religion } \\
\hline Christianity & 68 & 24 & 92 & 33.45 & \\
\hline Islamic & 121 & 35 & 156 & 56.73 & \\
\hline Traditional & 27 & - & 27 & 9.82 & \\
\hline Total & 216 & 59 & 275 & 100 & \\
\hline \multicolumn{6}{|l|}{ Experience } \\
\hline $0-5$ & 98 & 17 & 115 & 41.82 & \multirow[t]{5}{*}{7.06} \\
\hline $6-10$ & 57 & 28 & 85 & 30.91 & \\
\hline $11-15$ & 61 & 14 & 75 & 27.27 & \\
\hline $16-20$ & - & - & - & - & \\
\hline Total & 216 & 59 & 275 & 100 & \\
\hline
\end{tabular}

Table 1 shows the socio-demographic variables of respondents. 51 respondents $(18.55 \%)$ are within the age bracket of $15-25 ; 97$ respondents $(35.27 \%)$ are within the 
age bracket of $26-36 ; 37$ respondents $(13.45 \%)$ are within the age bracket of $37-47 ; 60$ respondents $(21.82 \%)$ are within the age bracket of 48 - 58; and 30 respondents $(10.91 \%)$ are within the age bracket of $59 \&$ above. The mean score indicates that majority of the respondents are 39 years old. From the table II, 118 respondents (42.91\%) were male; and 157 respondents $(57.09 \%)$ were female. The mode recorded for gender (157) implies that majority of the respondents is female. The table shows that 15 respondents $(5.45 \%)$ reported that they hold FSLC; 60 respondents $(21.82 \%)$ hold SSCE; 114 respondents $(41.45 \%)$ hold NCE (or its equivalent); 60 respondents $(21.82 \%)$ hold HND/ BSc; and 26 respondents $(9.45 \%)$ hold MSc (or its equivalent) and above. The mode (114) shows that majority of the respondents have NCE (or its equivalent). The table shows that 92 respondents $(33.45 \%)$ are Christians; 156 respondents $(56.73 \%)$ are Muslims; and 27 respondents $(9.82 \%)$ are traditional worshippers. The mode (156) shows that majority of the respondents are Muslims.

The results (in table 1) indicate that 115 respondents $(41.82 \%)$ have the 'experience' of about 5 years; 85 respondents $(30.91 \%)$ have the 'experience' of 6 - 10 years; 75 respondents $(27.27 \%)$ have the 'experience' of 11 - 15 years; and no respondent has the 'experience' of 31 - 40 years. The mean score (7.06) indicates that majority of the respondents have the 'experience' of about 7 years.

Table 2 Descriptive analysis of workforce diversity factors

\begin{tabular}{|c|c|c|c|c|c|c|c|c|}
\hline \multirow{3}{*}{$\begin{array}{l}\text { Variable } \\
\text { Factors }\end{array}$} & \multicolumn{8}{|c|}{ Workforce Diversity } \\
\hline & \multicolumn{8}{|c|}{ Frequency and Percentage } \\
\hline & $\mathrm{SA}(\%)$ & $\mathrm{A}(\%)$ & $\mathrm{UD}(\%)$ & $\mathrm{D}(\%)$ & $\mathrm{SD}(\%)$ & $\begin{array}{l}\text { Mean } \\
\text { Score }\end{array}$ & $\begin{array}{c}\text { Cut-off } \\
\text { Point }\end{array}$ & Decision \\
\hline Age & $104(48.1)$ & $66(30.6)$ & $12(5.6)$ & $12(5.6)$ & $22(10.2)$ & 4.009 & 3.050 & Accepted \\
\hline Religion & $131(60.6)$ & $39(18.1)$ & $12(5.6)$ & $16(7.4)$ & $18 \quad(8.3)$ & 4.153 & 3.050 & Accepted \\
\hline Educational & $79(36.6)$ & $86(39.8)$ & $17(7.9)$ & 4 (1.9) & $30(13.9)$ & 3.833 & 3.050 & Accepted \\
\hline \multicolumn{9}{|l|}{ Background } \\
\hline Job Experience & $110(50.9)$ & $69(31.9)$ & $25(11.6)$ & 12 (5.6) & - & 4.287 & 3.050 & Accepted \\
\hline Gender & $58(26.9)$ & $100(46.3)$ & $44(20.4)$ & $8 \quad(3.7)$ & $6(2.8)$ & 3.907 & 3.050 & Accepted \\
\hline Culture & $29(13.4)$ & $12(5.6)$ & $46(21.3)$ & $80(37.0)$ & $49(22.7)$ & 2.500 & 3.050 & Rejected \\
\hline physical ability & $7(3.2)$ & $18(8.3)$ & $12(5.6)$ & $66(30.6)$ & $113(52.3)$ & 1.796 & 3.050 & Rejected \\
\hline
\end{tabular}

Source: Field Survey, 2020

Table 2 shows workforce diversity factors among small firms in the study area. The factors which appear to be valid and reliable in association with diversity at the surveyed small firms in Kogi State are age, religion, educational background, job experience, gender, culture and physical ability. The mean score of age is 4.009; religion is 4.153; educational background is 3.833; job experience is 4.287 ; and gender is 3.907 as against the cut-off point of 3.050. Since the mean scores of these variables are greater than the cut-off point, they are accepted as prime factors of workforce diversity in the study area. In terms of educational background, Khoreva (2011) found that "the individuals who are more educated as judge against to who are less educated make out more gender difference" (p.234). It could be observed that variables such as age, religion and job experience seem to be the most severe workforce diversity factors. The table also shows that the mean score of culture (2.500) and physical ability of employees (1.796) do not enter as viable factors of 
workforce diversity in the study area. Though, these two factors may be present among the selected small firms, but they may be too insignificant to be noticed.

Table 3 Showing ANOVA for gender difference on the outcomes of small firms in Kogi State, Nigeria

\begin{tabular}{llcccc}
\hline Outcomes & & Female & Male & F-Value & F-Crit \\
\hline Concern for organizational performance & M & 2.1525 & 1.5763 & 7.334 & 1.5458 \\
& SD & 0.8054 & 0.6216 & & 1.5458 \\
Observed value for job and satisfaction & M & 2.2034 & 2.2542 & 18.495 & 1.5518 \\
& SD & 0.8047 & 0.7094 & & \\
Contribute effectively to output level & M & 2.0526 & 2.3509 & 9.505 & 1.55 \\
through initiative & SD & 0.8540 & 0.6121 & & 1.5458 \\
Talent for firm's competitiveness & M & 2.0678 & 2.0339 & 17.068 & \\
and advantage & SD & 0.8276 & 0.7420 & & \\
Good customer relation and customer & M & 2.2034 & 2.1525 & 7.781 & 1.5458 \\
satisfaction concern & SD & 0.8259 & 0.6647 & & \\
\hline \multicolumn{2}{c}{ Source: Field Survey, 2020 } & &
\end{tabular}

Firstly, table 3 shows the difference between female and male in terms of concern for organizational performance. Females have more concern for organizational performance (2.1525) compared to their male counterpart (1.5763). The standard deviation of concern for organizational performance for female $(0.8054)$ shows more divergence as compared to the male $(0.6216)$. The f-statistics value of 7.3341 appears to be greater than the Fcritical value (1.5458). This shows a clear difference in terms of concern for organizational performance between female and male employees of small firms in the study area. It is thus necessary to deduce that in many small firms in Kogi State, the female employees strive to ensure organizational performance (profitability) more than the male employees. In terms of gender differences affecting organizational performance, this finding refutes the assertion of Kalleberg \& Leicht (1991) and Weiliang et al. (2011) that "the performance criteria for success are expected to be higher for men than for women".

Secondly, the table shows that males have more value for their jobs and are satisfied with it (2.2542) compared to their female counterpart (2.2034). Though, the observed difference seems to be very little based on the compared mean scores. The standard deviation of observed job value and satisfaction among female (0.8047) shows more divergence as compared to the male (0.7094). The f-statistics value of 18.4951 appears to be greater than the F-critical value (1.5458). This result shows that male employees have more value for their jobs and are more satisfied with the job than the female counterpart of the small firms in the study area.

Thirdly, the table shows that males contribute more effectively to output level through their initiative (2.3509) compared to their female counterpart (2.0526). The standard deviation of female (0.8540) shows more divergence as compared to the male (0.6121). The f-statistics value of 9.5050 is greater than the F-critical value (1.5458). This result shows that male employees contribute more effectively to output level through their initiative than the female counterpart of the small firms in Kogi State.

Fourthly, the table shows that female possess more talent for firm's competitiveness and advantage (2.0678) compared to their male counterpart (2.0339). The standard deviation of female (0.8276) shows more divergence as compared to the male $(0.7420)$. 
The f-statistics value of 17.0684 is greater than the F-critical value (1.5458). This result shows that female employees possess more talent for firm's competitiveness and advantage than the male counterpart of the small firms in Kogi State.

Fifthly, the table shows that females have good customer relations and are more customer-satisfaction concerned (2.2034) compared to their male counterpart (2.1525). The standard deviation of female (0.8259) shows more divergence as compared to the male (0.6647). The f-statistics value of 7.7808 is greater than the F-critical value (1.5458). This result shows that female employees have good customer relations and are more customer-satisfaction concerned than the male counterpart of the small firms in Kogi State.

Table 4 Summary of Multiple Regression analysis of Potential Covariates with OP, JS and ET

\begin{tabular}{|c|c|c|c|c|c|c|c|c|c|c|c|c|c|c|c|}
\hline \multirow[t]{2}{*}{ Covariate } & \multicolumn{3}{|c|}{ Coefficients $(\beta)$} & \multicolumn{3}{|c|}{$\begin{array}{c}\text { Standard Error } \\
(\beta))\end{array}$} & \multicolumn{3}{|c|}{$\begin{array}{l}\text { Value of } \\
\text { t-Statistics }\end{array}$} & \multicolumn{3}{|c|}{ Value of $\mathrm{R}^{2}$} & \multicolumn{3}{|c|}{$\begin{array}{c}\text { Value of } \\
\text { F-Statistics }\end{array}$} \\
\hline & $\mathrm{OP}$ & JS & ET & $\mathrm{OP}$ & JS & ET & OP & JS & ET & OP & JS & ET & OP & JS & ET \\
\hline $\mathrm{AG}$ & .476 & .579 & -.084 & .205 & .144 & .341 & 2.322 & 4.029 & -.245 & .642 & .844 & .020 & 5.390 & $16.229^{*}$ & .060 \\
\hline RG & .897 & .552 & .099 & 248 & .519 & .574 & 3.623 & 1.063 & .172 & .814 & .274 & .010 & $13.126^{*}$ & 1.130 & .030 \\
\hline EB & .967 & 907 & -.079 & 132 & .310 & .575 & 7.304 & 2.926 & -.137 & .947 & .741 & .006 & $53.342^{* * *}$ & 8.559 & .019 \\
\hline $\mathrm{JE}$ & .769 & .566 & -.215 & .100 & .355 & .440 & 7.692 & 1.593 & -.488 & .952 & .458 & .074 & $59.164^{* *}$ & 2.539 & .238 \\
\hline
\end{tabular}

EB - Educational Background; JE - Job Experience; OP - Organizational Performance; JS - Job Satisfaction; JP - Job Performance; ET- Employee Turnover

The result (table 4) shows that $84.4 \%$ of the variation in job satisfaction is explained by age. The presence of $15.6 \%$ unexplained variation suggests that there are other predictor variables which affect variations in job satisfaction among small firms in Kogi State. The co-efficient for age $(0.579, \mathrm{p}<0.05)$ indicates 'positive relationship' with job satisfaction. The result shows that increase in the age of employees will account for $57.9 \%$ increase in job satisfaction. This aligns with the finding of Rehman et al. (2015) which found that one year more age leads to increase in job satisfaction. This implies that employees are prompted to be more satisfied with their jobs as they become of age in Kogi State. This could be as a result of age limit (27 years) placed on job seekers in Nigeria; this explains the minimal employee turnover rate. However, the $\mathrm{R}^{2}$-value of 0.844 shows a strong predictor. Thus, age has significant effect on job satisfaction of employees among small firms in Kogi State.

The result (table 4) reveals that $81.4 \%$ of the variation in the performance of small firms in Kogi State is explained by religious belief of employees. This may be from the fact that one religion's doctrine places limits on the level of female employees' initiatives and commitment to goal pursuit; and the other widely accepted religion teaches morals that encourages hard work in Nigerians' small firms. The presence of $18.6 \%$ unexplained variation suggests that there are other predictor variables affecting the performance of small firms in Kogi State, Nigeria. The co-efficient for religion $(0.897, \mathrm{p}<0.05)$ shows a positive relationship with organizational performance. This means that additional improvement in religious teachings effort will bring about $89.7 \%$ improvements in the performance of small firms in Kogi State. However, the $\mathrm{R}^{2}$-value of 0.814 shows a strong predictor. We therefore deduce that the religion of employees has strong significant effect on the performance of small firms in Kogi State, Nigeria. 
The Table also shows that $94.7 \%$ of the variation in the performance of small firms in Kogi State is explained by educational background of employees. The presence of $5.3 \%$ unexplained variation suggests that there are other predictor variables affecting the performance of small firms in Kogi State. The co-efficient for educational background $(0.967, p=0.01)$ shows a positive relationship with the performance of small firms in Kogi State. This implies that increase in knowledge and skill possessed by employees through learning will lead to $96.7 \%$ improvement in the performance of small firms in Kogi State. This agrees with the finding of Weiliang et al. (2011) that "there is significant positive relationship between education background and performance". It also agrees with the finding of Rehman et al. (2015) that a change in educational status will bring proportional improvement in organization performance. However, the $\mathrm{R}^{2}$-value $(0.947)$ indicates a strong predictor. We therefore deduce that educational background of employees has strong significant effect on the performance of small firms in Kogi State.

The result (table 4 ) indicates that $95.2 \%$ variation in the performance of small firms in Kogi State is explained by job experience of employees. The presence of $4.8 \%$ unexplained variation suggests that there are other predictor variables affecting the performance of small firms in Kogi State. The co-efficient for job experience $(0.769, \mathrm{p}=0.01)$ shows a positive relationship with the performance of small firms in Kogi State. This implies that increase in job experience of employees will lead to $76.9 \%$ improvement in the 'performance of small firms' in Kogi State. This aligns with the finding of Rehman et al. (2015) that there is positive relationship between experience and organization performance. This simply means that the more the employees accumulate experience on the job, the bigger the tendency for higher performance of small firms in Kogi State. However, the $\mathrm{R}^{2}$-value (0.952) indicates a strong predictor. We therefore deduce that job experience of employees has strong 'significant effect' on the performance of small firms in Kogi State.

\section{CONCLUSION AND RECOMMENDATIONS}

Some factors were investigated as triggering diversity in small firms in Kogi State. Factors such as age, religion, educational background, job experience, gender, culture and physical ability are found to be peculiar within small firms in Kogi State. Age, religion, educational background, job experience and gender are significantly strong factors; while culture and physical ability of employees are found weak and insignificant. These two factors may be present among the workforce of the small firms, but they appear to be too insignificant. Meanwhile, empirical investigation proves that age has 'significant positive effect on job satisfaction of employees' among small firms in Kogi State. Other factors such as religion, educational background and job experience of employees only affect the performance of these small firms in Kogi State positively.

Female employees are found significant to organizational success. The female employees of small firms in Kogi State are more spirited to pursuing the organizational performance (profitability, competitive advantage, productivity, market share, etc.). This is coupled with more excellent talent they possess; which can enhance their firm's competitiveness and advantage within the business environment of Kogi State. In addition, female employees have good customer relations and are more customer-satisfaction concerned than the male counterpart of the small firms in Kogi State. 
Though, the male employees appear to have more value for their jobs and are more satisfied with the job than the female counterpart of the small firms in Kogi State. The difference is apparently too little. Based on observed behaviour of employees in organizations in Nigeria, the economic situation of a particular period stimulates the job satisfaction of male employees. It is very much apparent that the female employees' turnover rate is low; and this is a pointer of job satisfaction. However, the result stipulates that male employees contribute more effectively to output level through their initiative than the female counterpart of the small firms in Kogi State. This may not have connection with the job value or job satisfaction of employees; as Nigerian women have long consented and maintained the fact that they are weaker virtue. In a nutshell, gender difference, if strategically managed, may influence organizational outcome positively.

Therefore, the study recommends that:

i. Owner-managers of small firms should take cognizance of age as a significant workforce diversity factor that affects job satisfaction of employees. This is because, the older an employee becomes on the job the more he/she is satisfied with the job in Kogi State.

ii. Owner-managers of small firms should strategically manage workforce diversity factors such as religion, educational background and job experience of employees; as they affect the performance of small firms in Kogi State. Proper management of these factors will enhance positive performance of small firms in Kogi State.

iii. Owner-managers should strategically manage gender difference in their firms to enhance organizational performance, job satisfaction, productivity, competitive advantage and customers' satisfaction.

\section{REFERENCES}

Andrade, S. (2010). Advantages of Workplace Diversity. Saharconsulting's Blog. Retrieved on July 27, 2019 from https://saharconsulting.wordpress.com/2010/03/26/6-advantages-of-workplace-diversity/

Andreoni, J., \& Miller, J. H. (1993). Rational Cooperation in the finitely repeated Prisoner's Dilemma: Experimental Evidence. Economic Journal, 103(418), 570-585.

Backes-Gellner, U., \& Veen, S. (2009). The Impact of Aging and Age Diversity on Company Performance. In E. C. Weiliang, L. K. Mun, T. S. Chern, T. S. Fong \& Y. P. Yuan (eds). The Effects of Workforce Diversity towards the Employee Performance in an Organization. A research project: Universiti Tunku Abdul Rahman

Bell, M. P., \& Berry, D. P. (2007). Viewing Diversity through Different Lenses: Avoiding a Few Blind Spots. Academy of Management Perspectives, 21(4), 21-25.

Choi, S., \& Rainey, H. G. (2010). Managing Diversity in U.S. Federal Agencies: Effects of Diversity and Diversity Management on Employee Perceptions of Organizational Performance. Public Administration Review, 70(1), 109-121. https://doi.org/10.1111/j.1540-6210.2009.02115.x

Clements, P. (2009). The Equal Opportunities Handbook: How to Recognise. Diversity, Encourage Fairness and Promote Anti-Discriminatory Practice. In E.C. Weiliang, L.K. Mun, T.S. Chern, T.S. Fong \& Y.P. Yuan (eds). The Effects of Workforce Diversity towards the Employee Performance in an Organization. A research project: Universiti Tunku Abdul Rahman

Cox, T. H., Lobel, S. A., \& McLeod, P. L. (1991). Effects of ethnic group cultural differences on cooperative and competitive behavior on a group task. Academy of Management Journal, 3(4), 827-847. https://doi.org/10.2307/256391

Ehimare, O. A., \& Ogaga-Oghene, J. O. (2011). The Impact of Workforce Diversity on Organizational Effectiveness: A Study of a Nigerian Bank. Annals of the University of Petroşani, Economics, 11(3), 93-110.

Gomez, L. E. \& Bernet, P. (2019). Diversity improves performance and outcomes. Journal of the National Medical Association, 111(4), 383-392, https://doi.org/10.1016/j.jnma.2019.01.006 
Hwang, J., \& Hopkins, K. M. (2015). A structural equation model of the effects of diversity characteristics and inclusion on organizational outcomes in the child welfare workforce. Children and Youth Services Review, 50, 44-52. https://doi.org/10.1016/j.childyouth.2015.01.012

Ibidunni, A. S., Falola, H. O., Ibidunni, O. M., Salau, O. P., Olokundun, M. A., Borishade, T. T., Amaihian, A. B., \& Peter, F. (2018). Workforce diversity among public healthcare workers in Nigeria: Implications on job satisfaction and organizational commitment. Data in Brief. 18, 1047-1053. https://doi.org/10.1016/j.dib. 2018.03.127

Jackson, S. E., Joshi, A., \& Erhardt, N. L. (2003). Recent Research on Team and Organizational Diversity: SWOT Analysis and Implications. Journal of Management, 2(9), 801-830. https://doi.org/10.1016/S01492063_03_00080-1

Jayne, M. E., \& Dipboye, R.L. (2004). Leveraging diversity to improve business performance: research findings and recommendations for organizations. Human Resource Management, 43(4), 409-424. https://doi.org/10.1002/ hrm.20033

Jehn, K. A., Chatwick, C., \& Thatcher, S. M. (2007). To agree or not to agree: The effects of value congruence, individual demographic dissimilarity, and conflict on workgroup outcomes. International Journal of Conflict Management, 8(4), 287-305. https://doi.org/10.1108/eb022799

Kalev, K. (2006). Training Manual on Conflict Management, the National Unity and Reconciliation Commission, Republic of Rumanda. In E.C. Weiliang, L.K. Mun, T.S. Chern, T.S. Fong \& Y.P. Yuan (eds). The Effects of Workforce Diversity towards the Employee Performance in an Organization. A research project: Universiti Tunku Abdul Rahman

Kalleberg, A. L., \& Leicht, K. T. (1991). Gender and Organizational Performance: Determinants of Small Business Survival and Success. Academy of Management Journal. 34(1), 136-161. https://doi.org/10.2307/256305

Khoreva, V. (2011). Gender pay gap and its perceptions. An International Journal, 30(3), 233-248. https://doi.org/10.1108/02610151111124969

Klein, K. J., \& Harrison, D. A. (2007). On the Diversity of Diversity: Tidy Logic, Messier Realities. Academy of Management Perspectives, 21(4), 26-33. Retrieved on May 21 ${ }^{\text {st }}, 2017$ from https://www.jstor.org/stable/ 27747409

Knippenberg, D. V., De Dreu, K. W., \& Homan, A. C. (2004). Work Group Diversity and Group Performance: An Integrative Model and Research Agenda. Journal of Applied Psychology, 89(6), 1008-1022. https://doi.org/10.1037/0021-9010.89.6.1008

Kochan, T., Bezrukova, K., Ely, R., Jackson, S., Joshi, A., Jehn, K., Leonard, J., Levine, D., \& Thomas, D. (2003). The Effects of Diversity on Business Performance: Report of the Diversity Research Network. Human Resource Management, 42(1), 3-21. https://doi.org/10.1002/hrm.10061

Kokemuller, N. (2011). What Is Diversity and How Does It Impact Work?" Retrieved on April 6 ${ }^{\text {th }}, 2020$ from: http://smallbusiness.chron.com/diversity-impact-work-15985.html

Konrad, A. (2003). Defining the domain of workplace diversity scholarship. Group \& Organization Management, 28(1), 4-17. https://doi.org/10.1177/1059601102250013

Lindblad, M. (n.d). Causes \& Effects of Diversity in the Workplace. Retrieved on May $27^{\text {th }}$, from http://smallbusiness.chron.com/causes-effects-diversity-workplace-26003.html

Madanchian, M., Hussein, N., Noordin, F., \& Taherdoost, H. (2017). Leadership effectiveness measurement and its effect on organization outcomes. Procedia Engineering, 181, 1043-1048. https://doi.org/10.1016/ j.proeng.2017.02.505

Milliken, F., \& Martins, L. (1996). Searching for common threads: Understanding the multiple effects of diversity in organizational groups. In D.V. Knippenberg, K.W. De Dreu \& A.C. Homan (eds). Work Group Diversity and Group Performance: An Integrative Model and Research Agenda. Journal of Applied Psychology, 89(6), 1008-1022. https://doi.org/10.1037/0021-9010.89.6.1008

Milliken, F. J., \& Martins, L. L. (1996). Searching for Common Threads: Understanding the Multiple Effects of Diversity in Organizational Groups. Academy of Management Review, 21(2), 402-34. https://doi.org/ $10.2307 / 258667$

Mor-Barak, M. (2005). Managing Diversity: Towards a Globally Inclusive Workplace, Thousand Oaks, California CA: Sage

Mulholland, G., Ozbilgin, M., \& Worman, D. (2005). Managing Diversity Linking Theory and Practice to Business Performance. In O.A. Ehimare \& J.O. Ogaga-Oghene (eds). The Impact of Workforce Diversity on Organizational Effectiveness: A Study of a Nigerian Bank. Annals of the University of Petroşani, Economics, 11(3), 93-110.

Ongori, H. \& Agolla, J. E. (2007). Critical review of literature on workforce diversity. African Journal of Business Management, 3(2), 072-076.

Patrick, H. A., \& Kumar, V. R. (2012). Managing Workplace Diversity: Issues and Challenges. SAGE Open Journal, April-June, 1-15. https://doi.org/10.1177/2158244012444615 
Pitts, D. W., Hicklin, A. K., Hawes, D. P., \& Melton, E. (2010). What Drives the Implementation of Diversity Management Programs? Evidence from Public Organizations. Journal of Public Administration Research \& Theory, 20(4), 867-886. https://doi.org/10.1093/jopart/mup044

Rahman, S., Ferdausy, S., \& Bhattacharjee, S. (2014). Assessing the Relationships among Transformational Leadership, Transactional Leadership, Job Performance and Gender: An Empirical Study. ABAC Journal, 34(3), 71-91.

Rehman, R., Ullah, M. I., \& Abrar-ul-haq, M. (2015). The Influence of Individual Characteristics on Organization Performance and Job Satisfaction. International Journal of Scientific and Research Publications, 5(2), 1-6.

Roberge, M., \& Rolf, D. (2010). Recognizing the benefits of diversity: When and how does diversity increase group performance?. Human Resource Management Review, 20(4), 295-308. https://doi.org/10.1016/j.hrmr.2009. 09.002

Saxena, A. (2014). Workforce Diversity: A Key to Improve Productivity. Procedia Economics and Finance, 11(SIMSARC13), 76-85. https://doi.org/10.1016/S2212-5671(14)00178-6

Seyed-Mahmoud, A. (2004). Managing workforce diversity as an essential resource for improving organizational performance. International Journal of Productivity and Performance Management, 53(6), 521-531. https://doi.org/10.1108/17410400410556183

Strauss, M. (1999). Culture Shocks in inter-cultural service encounters?. Journal of Services Marketing, 123(4/5), 329-346. https://doi.org/10.1108/08876049910282583

Tsui, A. S., Egan, T. D., \& O’Reilly, C. A. (1992). Being different: Relational demography and organizational attachment. In D.V. Knippenberg, K.W. De Dreu \& A.C. Homan (eds). Work Group Diversity and Group Performance: An Integrative Model and Research Agenda. Journal of Applied Psychology, 89(6), 10081022. https://doi.org/10.1037/0021-9010.89.6.1008

Webber, S. S., \& Donahue, L. M. (2001). Impact of highly and less job-related diversity on work group cohesion and performance: A meta-analysis. Journal of Management, 27, 141-162. https://doi.org/10. $1177 / 014920630102700202$

Weiliang, E. C., Mun, L. K., Chern, T. S., Fong, T. S., \& Yuan, Y. P. (2011). The Effects of Workforce Diversity towards the Employee Performance in an Organization. A research project: Universiti Tunku Abdul Rahman

Williams, K. Y., \& O’Reilly, C. A. (1998). Demography and diversity in organizations: A review of 40 years of research. In D.V. Knippenberg, K.W. De Dreu \& A.C. Homan (eds). Work Group Diversity and Group Performance: An Integrative Model and Research Agenda. Journal of Applied Psychology, 89(6), 10081022. https://doi.org/10.1037/0021-9010.89.6.1008

\section{ISTRAŽIVANJE DIVERZITETA NA RADNOM MESTU U MALIM FIRMAMA U SAVEZNOJ DRŽAVI KOGI U NIGERIJI}

Ova studija ima za cilj istraživanje diverziteta na radnom mestu u malim preduzećima $u$ saveznoj državi Kogi u Nigeriji. Studija je koristila model upitnika, a za analizu podataka korišćeni su deskriptivna statistika, srednja vrednost Likert skale, ANOVA i višestruka regresija. Studija je ustanovila da starost ispitanika ima značajnog uticaja na zadovoljstvo poslom kod zaposlenih; a da religija, obrazovni profil i radno iskustvo imaju izražen značajni uticaj na organozacione ishode malih preduzeća u državi Kogi. Nalazi dalje pokazuju da pol utiče na organizacioni učinak, zadovoljstvo poslom, produktivnost, konkurentsku prednost i zadovoljstvo mušterija. Studija zaključuje da starost ima značajan pozitivni uticaj na zadovoljstvo poslom, a drugi faktori kao što su religija, obrazovni profil i radno iskustvo samo utiču pozitivno na poslovanje malih preduzeća u državi Kogi . Preporuka je stoga da vlasnici-menadžeri malih preduzeća uzmu u obzir starost zaposlenih jer ona utilče na zadovoljstvo poslom, i treba strateški da upravljaju faktorima kao što su religija, obrazovni profil i radno iskustvo jer oni utiču na učinak.

Ključne reči: diverzitet, zadovoljstvo poslom, organizacioni ishodi, fluktuacija zaposlenih, organizaciona kultura 